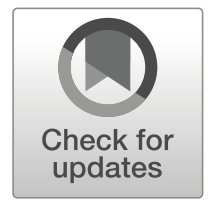

\title{
Species turnover and low stability in a community of euglossine bees (Hymenoptera: Apidae) sampled within 28 years in an urban forest fragment
}

\author{
Léo Correia da Rocha-Filho ${ }^{1}$, Paula Carolina Montagnana ${ }^{2}$, Danilo Boscolo ${ }^{2}$, \\ Carlos Alberto GARÓFALO ${ }^{2}$
}

\author{
${ }^{1}$ Instituto de Biologia - INBIO, Universidade Federal de Uberlândia - UFU, 38400-732, Uberlândia, MG, Brazil \\ ${ }^{2}$ Departamento de Biologia, Faculdade de Filosofia, Ciências e Letras de Ribeirão Preto (FFCLRP), Universidade de São \\ Paulo (USP), Ribeirão Preto, São Paulo 14040-901, Brazil
}

Received 26 November 2019 - Revised 2 March 2020 - Accepted 7 April 2020

\begin{abstract}
Orchid bees are important long-distance pollinators in Neotropical rainforests. Despite their great flight capacity, some species avoid leaving the forest and might be then more vulnerable to the negative effects of habitat fragmentation. Here, we sampled the euglossine fauna from a forest fragment in an urban zone and compared the data to two surveys conducted in the same area 28 and 20 years before. Twelve species were sampled, and the highest values of both abundance and richness were recorded in the present sampling. Species turnover was observed with the resilient species Euglossa cordata and Eulaema nigrita presenting a high increase in number over the years whereas the prevalent species in the former samplings, Euglossa pleosticta, show the highest stable populations. Conversely, the abundance of Euglossa annectans decreased until zero in the last sampling. The studied orchid bee populations had a lower stability value when compared with other euglossine long-term surveys. Our results indicate that even a small forest fragment within an urbanised landscape and subjected to different levels of anthropogenic impacts harbours a diverse euglossine fauna. It is suggested that not only the preservation and maintenance of forest fragments in urban areas but also its restoration after environmental impacts are important procedures to support species-rich wildlife.
\end{abstract}

\section{Euglossa cordata / Eulaema nigrita / Long term / Orchid bees / Resilient species}

\section{INTRODUCTION}

Orchid bees (Apidae: Euglossini) consist of approximately 250 species distributed from southern USA to northern Argentina (Michener 2007; Ascher and Pickering 2020), but the highest diversity is found in tropical rainforests of South America (Dressler 1982; Roubik and Hanson 2004). These bees are recognised as keystone pollinators of a myriad of Neotropical plants

Corresponding author: L. Rocha-Filho, correiadarocha@yahoo.com.br Handling Editor: Klaus Hartfelder
(Dodson 1966; Dressler 1982; Rocha-Filho et al. 2012; Ospina-Torres et al. 2015), especially orchids, since ca 700 species are exclusively pollinated by euglossine males (Roubik and Hanson 2004). Because of their long tongues, orchid bees are able to forage on long-tubed corolla flowers, which are inaccessible to other insects, expanding then the range of plant species visited for nectar collection (Dressler 1982). In addition, the analysis of the pollen content stored by females in brood cells revealed a polylectic behaviour and high diversity of plant species (Ramírez-Arriaga and Hernández 1998; Cortopassi-Laurino et al. 2009; Ferreira-Caliman et al. 2018), corroborating the important role of these bees in the 
reproductive success of tropical plants. Whilst females collect pollen and nectar for brood cell provisioning and resin (in some cases mud, faeces, and pieces of bark) to construct their nests, males feed on nectar and gather aromatic compounds from flowers to be presumably used to attract females (Dodson 1966; Michener 2007; Roubik and Hanson 2004). Due to this unique behaviour of perfume collection, several studies and surveys have been performed by using synthetic volatile compounds as scent baits to lure bee males (Dressler 1982; Raw 1989; Botsch et al. 2017; Cândido et al. 2018; Ferronato et al. 2018; Allen et al. 2019; Pinto et al. 2019). Another remarkable feature of euglossine bees is their great dispersal capacity that allows them to cross more than $20 \mathrm{~km}$ in a day in continuous forested areas (Janzen 1971; Raw 1989; Pokorny et al. 2015). However, despite being able to fly long distances, some orchid bee species avoid leaving the forest and might be then more vulnerable to the negative effects of habitat loss and fragmentation (Powell and Powell 1987; Milet-Pinheiro and Schlindwein 2005; Brosi 2009; Rosa et al. 2015).

Habitat fragmentation is a process by which continuous natural ecosystems are subdivided into smaller pieces leading to the isolation and reduction of species populations that are surrounded by a matrix of human-transformed land cover (Rathcke and Jules 1993). The destruction, degradation, and fragmentation of habitats are indicated as the primary causes of biodiversity loss besides invasive alien species, nitrogen pollution, overexploitation, and climate change impacts (Butchart et al. 2010). Birds, mammals, plants, and arthropods have been demonstrated to be negatively affected by the conversion of tropical forests into agricultural lands in 28 countries, with biodiversity values significantly lower in disturbed forested areas when compared with primary forests (Gibson et al. 2011). Regarding insects, the orders Lepidoptera, Hymenoptera, and Coleoptera seem to be the most impacted taxa by pronounced declines mainly associated to habitat loss and land conversion into agriculture and urbanisation (Sánchez-Bayo and Wyckhuys 2019).

Nevertheless, the abundance and species richness are not necessarily reduced in human-altered environments, but life history traits such as phenology and phylogenetic composition can vary. For instance, in surveys of 36 sites across forested, agricultural, and urban landscapes, Harrison et al. (2017) observed that native forest landscapes and anthropogenic areas differed strongly concerning the community phenology, species, and phylogenetic composition of bees. Likewise, some ecological traits like body size, activity period, and social behaviour allowed the colonisation of the urban core by some bee species along an urban gradient in Poland (BanaszakCibicka and Żmihorski 2012). Therefore, preserved forest fragments immersed in an anthropogenic matrix might act as important refuges for wildlife. Cândido et al. (2018) sampled a diverse orchid bee fauna in 10 forest fragments ranging from 1.6 to 162.3 ha within the urban landscape of a city in the Amazon domain. Similar results were also documented by other authors in different forest fragments located within urban areas (Nemésio et al. 2015; Cordeiro et al. 2019) or surrounded by monocultures (Milet-Pinheiro and Schlindwein 2005). The orchid bee communities sampled in these studies are characterised by the presence of resilient species with high tolerance to open, non-forested, or disturbed areas and some species that are only recorded in well-preserved fragments or within the forest (Milet-Pinheiro and Schlindwein 2005; Nemésio et al. 2015; Cândido et al. 2018; Cordeiro et al. 2019).

In this study, we sampled the orchid bee fauna from a seasonal semideciduous forest fragment immersed in the urban perimeter of a mediumsized city in south-eastern Brazil. This natural ecosystem was previously studied concerning the composition of euglossine bees 28 years (Garófalo, unpubl. data) and 20 years ago (Jesus 2000). Considering the city expansion area from the past 20 years and a fire event that consumed $46 \%$ of the forest fragment 4 years before the fieldwork conducted in the present study (Turioni 2014), we hypothesised that the orchid bee diversity would be lower when compared with the previous samplings. In addition, given that some orchid bee species seem to be more susceptible to habitat alteration and degradation (Powell and Powell 1987; Giangarelli et al. 2009; Ferronato et al. 2018), we expected to record a higher abundance of species commonly found in 
urban and/or altered areas (Raw 1989; Aguiar and Gaglianone 2012; Nemésio et al. 2015; Cordeiro et al. 2019) when compared with species considered to be more environmentally sensitive.

\section{MATERIALS AND METHODS}

\subsection{Study site}

Fieldwork was carried out at the Ecological Station of Ribeirão Preto (ESRP) ( $21^{\circ} 13^{\prime} 18^{\prime \prime}$ $\left.\mathrm{S} / 47^{\circ} 50^{\prime} 51^{\prime \prime} \mathrm{W}\right)$ located in the municipality of Ribeirão Preto, São Paulo State, south-eastern Brazil. The ESRP consists of 154.2 ha and is one of the largest fragments of seasonal semideciduous forest in the municipality, which encompasses a total of 102 fragments of natural vegetation that corresponds to $3.9 \%$ of the city area (KotchetkoffHenriques et al. 2005; Leonel et al. 2010). The forest fragment flora is composed of 283 species with most of them distributed in the plant families Fabaceae, Rubiaceae, Myrtaceae, Euphorbiaceae, and Rutaceae (Leonel et al. 2010). Moreover, 126 bird species were sampled in the area, including some threatened species in the São Paulo state as the orange-winged parrot Amazona amazonica (Linnaeus) (Psittacidae), the Crimson-crested woodpecker Campephilus melanoleucos (Gmelin) (Picidae), and the grey-headed tanager Eucometis penicillata (Spix) (Thraupidae) (Leonel et al. 2010). Despite being home of a species-rich fauna and flora, the ESRP buffer zone has only $17 \%$ of vegetation cover, which is distributed in 129 patches and $70 \%$ of the zone is located in the urban or urban expansion area (Varanda et al. 2015). In spite of being highly fragmented and hosting a biodiversity typically found in degraded areas, the buffer zone is also home of endangered species as the cougar Puma concolor (Linnaeus) and the ocelot Leopardus pardalis (Linnaeus) (Felidae) (Varanda et al. 2015).

In 2014, 72 ha (46\%) of the forest fragment was consumed by a fire that lasted for 3 days, which might have been caused by candles used in religious ceremonies that were already reported in the area (Leonel et al. 2010; Turioni 2014). In addition to this fire event, garbage deposition and pet abandonment are also threats to the conservation status of this forest fragment (Leonel et al. 2010).
Ribeirão Preto city is located in a region that includes areas of two biomes: the Brazilian savannah (Cerrado), which corresponds to $0.8 \%$ of the city area, and the semideciduous seasonal forest, represented by $1.4 \%$ of the urban area (Kotchetkoff-Henriques et al. 2005). The city has a total area of $650.9 \mathrm{~km}^{2}$ with a human population density of 928.9 inhabitants $/ \mathrm{km}^{2}$ (IBGE 2020). According to Köppen system, the climate in Ribeirão Preto region is classified as Aw, which is characterised by a cold/dry season (from April to September) and a hot/rainy season (from October to March) (Elias 2003).

\subsection{Bee sampling}

In order to obtain standardised data for comparison with the previous studies, we employed the same methodology used by Garófalo (unpubl. data) and Jesus (2000) in the ESRP. Samplings were conducted once a month from $9 \mathrm{~h} 00$ to $12 \mathrm{~h} 00$, a period with high activity of orchid bee males (Santos and Sofia 2002). Three scent baits were displayed at the edge of the forest fragment containing each $1 \mathrm{ml}$ of the following chemical substances: 1,8-cineole, eugenol, and vanillin, three effective aromatic compounds that are extensively used to attract euglossine males (Brosi 2009; Nemésio et al. 2015; Cordeiro et al. 2019). Scent baits made of absorbent paper balls with $1 \mathrm{ml}$ of each compound were attached with strings to vegetation branches up to $1.5 \mathrm{~m}$ from the soil. The scent baits were apart from each other at least $5 \mathrm{~m}$. The paper balls were replenished with an extra $1 \mathrm{ml}$ every hour given the volatile character of the aromatic compounds. Orchid bee males were captured with entomological net when landed in the paper balls. The captured males were identified using the following keys: Rebêlo and Moure (1995) and Roubik and Hanson (2004). Voucher specimens are deposited in the 'Coleção de Abelhas e Vespas Solitárias' of the Faculdade de Filosofia, Ciências e Letras de Ribeirão PretoUSP.

Another sampling was conducted in the ESRP (Alonso et al., unpubl. data) but not used for diversity data comparison since the methodology was different. In that study, the authors carried out the fieldwork for only 4 months, from October 
2005 to January 2006, and the hours of sampling ranged between $9 \mathrm{~h} 00$ and $13 \mathrm{~h} 00$. Additionally, they collected orchid bee males in two sampling points: one inside the forest fragment and the other at the edge (Alonso et al., unpubl. data). Thus, only the species composition and abundance recorded in that study were used to discuss the data.

The samplings in the present study were performed from March 2018 to February 2019. Garófalo (unpubl. data) carried out the fieldwork from March 1990 to February 1991, 28 years before the fieldwork performed herein whilst Jesus (2000) conducted the orchid bee samplings between September 1998 and August 1999, i.e., nearly 20 years before the present sampling.

\subsection{Data analyses}

The Shannon-Wiener index $\left(H^{\prime}\right)$ was calculated to estimate the diversity of the bee communities sampled in the different sampling years. The values calculated were further compared using $t$ tests. The Pielou's evenness index $\left(J^{\prime}\right)$ was used to show if the abundance of the sampled species was uniform $\left(J^{\prime}=1\right)$ or not $\left(J^{\prime}=0\right)$ in the community. The dominant species in the community were estimated by calculating the Berger-Parker dominance index $(d)$. The Kruskal-Wallis test was performed to check if the abundance of the species sampled in the three sampling years differed significantly. Pearson correlation tests were conducted to assess the association between the number of orchid bee males collected monthly in each of the three studied years (1990/1991, 1998/1999, and 2018/2019) and climate conditions (mean monthly temperature and monthly accumulated precipitation) of Ribeirão Preto city. The significance level used was 5\%. The free software PAST 2.17 (Hammer et al. 2001) was used to calculate all diversity indices and statistical tests, which followed Zar (1996).

The temperature and precipitation data from March to December 1990 were obtained from Instituto Agronômico de Campinas (IAC) whereas the remaining data were retrieved from the online database 'Centro Integrado de Informações Agrometeorológicas’ (CIIAGRO 2019).
In order to compare our data with previous studies on the stability of orchid bee communities (Roubik and Ackerman 1987; Nemésio et al. 2015), we used the stability index (SI) described by Wolda (1983) to measure how stable the population of a given species was throughout the three sampling years. The SI is calculated by the mean of the variance of the natural logarithm of annual abundance (Roubik and Ackerman 1987) and is given by the formula $\mathrm{SI}=\ln \left(\operatorname{var}\left\{\ln \left[N_{i}+1\right]\right\}\right)$, where $N_{i}$ is the number of orchid bee males of a given species captured in the year $i$ (Wolda 1983). Following Wolda's (1983) recommendation, species with mean annual natural logarithm $N$ of less than 0.6 are considered rare and were not included in the analyses because of their small variances in abundance values. The SI index for the community was then calculated by including only the mean of indices of all species whose mean natural logarithm of annual abundance was $>0.6$ (Wolda 1983).

Land cover maps of Ribeirão Preto city from the sampling years 1990, 1998, and 2018 were retrieved from the online platform MapBiomas collection v.4.0 (2019), available at https://mapbiomas. org/ (MapBiomas 2019). The MapBiomas base map was cut to the political limits of the municipality of Ribeirão Preto and reclassified into 5 main classes, namely native vegetation areas (both semideciduous forest fragments and Brazilian savannah areas), agricultural lands (including pastures), urban areas, water, and other cover types (Figure 1). The ESRP was included in the final map as native vegetation area among the other native vegetation patches. Additionally, in view of the great flight capacity of orchid bees in continuous forests (Janzen 1971), we calculated the proportion of these five land cover units within 5, 10, and 20$\mathrm{km}$ radii of the sampling point at the ESRP (Figure 2). Land cover of each of these classes within Ribeirão Preto municipality and in the three different buffers was measured for each year using Fragstats 4.2 (McGarigal et al. 2012) in order to calculate putative land cover changes over the years.

\section{RESULTS}

The community of orchid bees sampled in the ESRP in three different years was composed of 12 

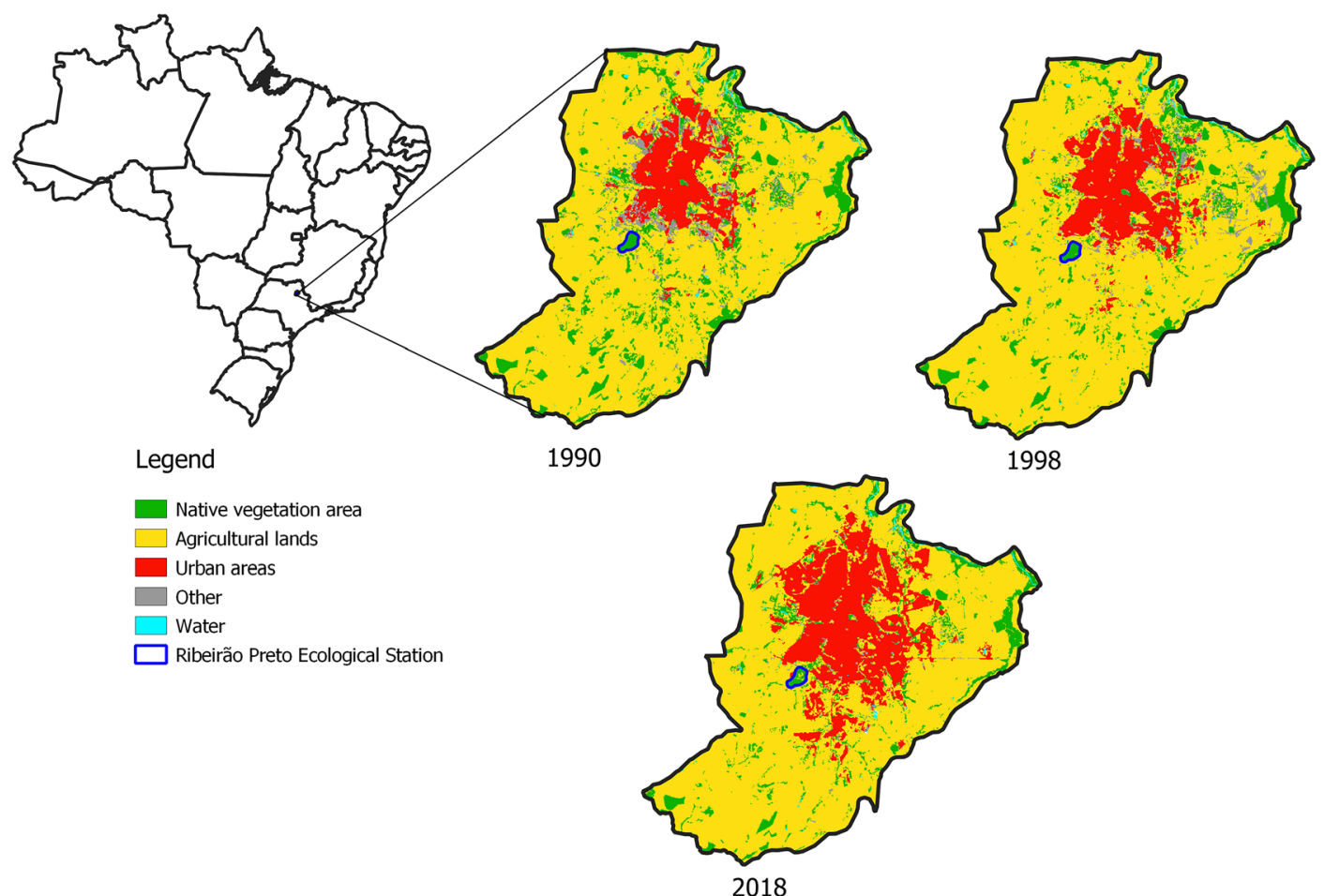

Figure 1. Location of the study area in south-eastern Brazil and the analysed images of Ribeirão Preto City in three different years (1990, 1998, and 2018).

species belonging to four genera (Table I). The sampling year with the highest richness was 2018/ 2019 with 10 species recorded whereas eight orchid bee species were sampled in the other two previous samplings. The species Euglossa securigera and Eulaema cingulata were recorded only in the last sampling, and the other two previous samplings differed regarding the presence of the two Eufriesea species: Ef. surinamensis recorded only in 1990/1991 and Ef. violacea sampled only in 1998/1999 (Table I). The first two samplings were characterised by the high prevalence of Euglossa pleosticta followed by Eulaema nigrita, and Euglossa annectans, with Euglossa cordata also being the third most sampled species in 1998/1999.

Species turnover was observed in the most recent sampling with Eg. cordata as the dominant species whilst the second and third most abundant species were El. nigrita and Eg. pleosticta (Table I). Euglossa annectans, the third most sampled species in 1990/1991 and
$1998 / 1999$, was the only species not recorded in 2018/2019.

The Shannon index values differed significantly between the first and third samplings $(t=3.23$; $p=0.001)$ and between the second and third samplings $(t=3.4 ; p=0.0007)$. The highest $H^{\prime}$ value was estimated for the second sampling when the lower abundance values were observed. This sampling also had the highest equitability $(J=0.75)$ and dominance $(d=0.48)$ values (Table I).

The abundance of Euglossa cordata ( $p=$ $0.0003)$ and El . nigrita $(p=0.006)$ varied significantly throughout the three sampling years, with an increasing number of males reported in $2018 / 2019$. Likewise, a higher number of Euglossa fimbriata $(p=0.01)$ males were observed in the most recent sampling. Conversely, the abundance of Eg. annectans $(p=0.0001)$ decreased along the sampled years, and no males of this species were collected in the last sampling (Table I). Variations in abundance were also 

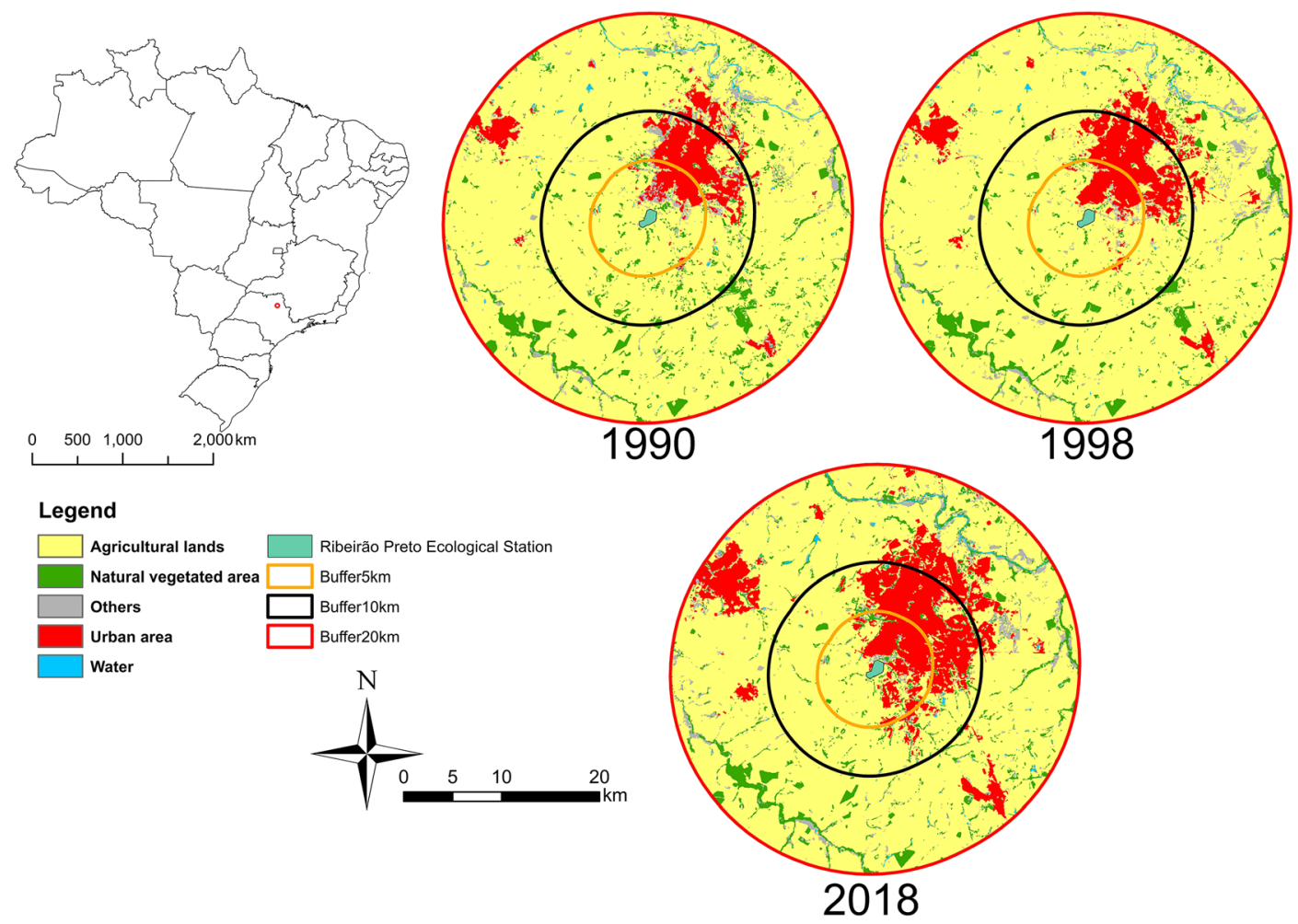

Figure 2. Composition of the 5, 10, and 20-km radii sampled area (ESRP) with mapped land cover colour legends in three different years (1990, 1998, and 2018).

observed for the other species, but the values were not statistically different. Whilst the number of $E f$. violacea and Euglossa truncata males diminished throughout the years, the cleptoparasitic species Exaerete smaragdina, similarly to its host El . nigrita (Garófalo and Rozen 2001), presented a higher abundance in 2018/2019 when compared with the other years (Table I).

The species Euglossa townsendi was only recorded by one male collected in the short-term sampling performed in 2005/2006 (Alonso et al., unpubl. data). The most abundant species in that sampling was $E g$. cordata followed by $E g$. pleosticta and El. nigrita. Besides, the species $E g$. annectans was also recorded even though with a much lower abundance when compared with the previous samplings. The species composition sampled by Alonso et al. (2006), unpubl. data was similar to what was observed in the other studied years (Table I).
Monthly bee abundance was positively correlated with monthly mean temperature in the two last samplings: $2018 / 2019(r=0.79 ; p=0.002)$ and $1998 / 1999(r=0.77 ; p=0.003)$, but no correlation was found in the first sampling $(1990 / 1991-r=0.49 ; p=0.1)$. There was no correlation observed between monthly accumulated precipitation and males' abundance in any of the three sampling years: $1990 / 1991(r=0.24$; $p=0.45), 1998 / 1999(r=0.57 ; p=0.06)$, and $2018 / 2019(r=0.45 ; p=0.14)$.

The SI index estimated for the community studied was -1.13 , a negative value that indicates a stable community (Table I). All values calculated for the species were also negative with $E g$. pleosticta $(-2.98)$ as the highest stable population sampled. The least stable populations presented wide fluctuation patterns. Whilst the species Eg. cordata $(-0.25)$ and El. nigrita $(-0.85)$ increased significantly, Eg. annectans 
Table I.. Abundance, diversity, and SI indices of Euglossini species sampled in three different years from March 1990 to February 2019 at the ecological station of Ribeirão Preto

\begin{tabular}{lcccccc}
\hline \multicolumn{1}{c}{ Species } & $1990 /$ & $1998 /$ & $2005 /$ & $2018 /$ & $\begin{array}{c}\text { Kruskal- } \\
\text { Wallis }\end{array}$ & SI \\
& 1991 & 1999 & $2006^{\mathrm{a}}$ & 2019 & - & - \\
\hline Eufriesea surinamensis (Linnaeus) & 2 & - & - & 5 & $p=0.34$ & -0.44 \\
Eufriesea violacea (Blanchard) & - & 15 & 22 & 3 & $p=0.33$ & -0.1 \\
Euglossa annectans Dressler & 47 & 23 & 6 & - & $p=0.0001^{*}$ & -0.25 \\
Euglossa cordata (Linnaeus) & 16 & 23 & 200 & 396 & $p=0.0003^{*}$ & -0.69 \\
Euglossa fimbriata Moure & 30 & 7 & 19 & 61 & $p=0.01^{*}$ & -0.69 \\
Euglossa pleosticta Dressler & 155 & 135 & 167 & 152 & $p=0.86$ & -2.98 \\
Euglossa securigera Dressler & - & - & - & 1 & $p=0.37$ & - \\
Euglossa townsendi Cockerell & - & - & 1 & - & $p=0.37$ & - \\
Euglossa truncata Rebêlo \& Moure & 13 & 17 & 2 & 4 & $p=0.4$ & -1.06 \\
Eulaema cingulata (Fabricius) & - & - & - & 1 & $p=0.37$ & - \\
Eulaema nigrita Lepeletier & 133 & 56 & 71 & 324 & $p=0.006^{*}$ & -0.85 \\
Exaerete smaragdina (Guérin) & 5 & 3 & 6 & 11 & $p=0.1$ & -1.24 \\
Community & - & - & - & - & - & -1.13 \\
$H^{\prime}$ & 1.5 & 1.55 & 1.42 & 1.33 & & \\
$J$ & 0.72 & 0.75 & 0.65 & 0.58 & & \\
d & 0.39 & 0.48 & 0.41 & 0.41 & & \\
Richness & 8 & 8 & 9 & 10 & & \\
Abundance & 401 & 279 & 494 & 958 & & \\
\hline
\end{tabular}

${ }^{a}$ Data not used for diversity values comparison but only to demonstrate the species composition sampled *Values significantly different between the sampling years

populations $(-0.1)$, in turn, decreased until zero in the last sampling (Table I).

The analyses of satellite images revealed that the native vegetation areas present within the Ribeirão Preto city region reduced $21 \%$ in size from 1990 until 1998 and 20.4\% from 1998 until 2018 (Table II). The ESRP area had a reduction of 5.5 ha from 1990 to 1998 , but from 1998 to 2018, the area lost at least 14.3 ha mainly due to the fire event that occurred in 2014 (Table II). On the other hand, the natural vegetated area increased throughout the analysed years within 5, 10, and $20-\mathrm{km}$ radii (Table III). From 1990 to 1998, the percentage of forest fragments and Brazilian savannah areas reduced from 11.7 to $37.5 \%$ within all analysed radii whilst this proportion augmented up to $206.6 \%$ from 1998 to 2018 (Table III).

\section{DISCUSSION}

The species composition recorded in the ESRP is similar to what was documented by other authors in seasonal semideciduous forest fragments located in south-eastern and southern Brazil with some differences concerning the abundance values and presence/absence of less frequent species (Rebêlo and Garófalo 1991, 1997; Sofia et al. 2004; Aguiar and Gaglianone 2012; Knoll and Penatti 2012; Mateus et al. 2015; Nemésio et al. 2015; Ferronato et al. 2018; Cordeiro et al. 2019).

Our first hypothesis on a lower species diversity estimated in 2018/2019 when compared with the previous samplings was rejected since the community studied recently presented not only a slightly higher number of species than those sampled in 1998/1999 and 1990/1991 but also a pronounced increase in males' abundance. Two rare 
Table II.. Percentage of land cover units measured from satellite images of Ribeirão Preto City of three different years: 1990,1998 , and 2018

\begin{tabular}{|c|c|c|c|c|c|c|}
\hline \multirow[t]{2}{*}{ Land cover units } & \multicolumn{2}{|c|}{1990} & \multicolumn{2}{|c|}{1998} & \multicolumn{2}{|c|}{2018} \\
\hline & $\%$ & Area (ha) & $\%$ & Area (ha) & $\%$ & Area (ha) \\
\hline Natural vegetation area & 12.2 & 7920.9 & 9.6 & 6255.9 & 7.7 & 4982.3 \\
\hline Agricultural lands & 74.1 & $48,204.8$ & 74.4 & $48,430.7$ & 71 & $46,213.5$ \\
\hline Urban areas & 9.7 & 6312.7 & 12.9 & 8372.0 & 19.9 & $12,958.6$ \\
\hline Water & 0.5 & 330.1 & 0.5 & 314.8 & 0.5 & 350.8 \\
\hline Other cover types & 3.5 & 2308.8 & 2.6 & 1713.2 & 0.9 & 569.0 \\
\hline Total & 100 & $65,077.3$ & 100 & $65,086.6$ & 100 & $65,074.1$ \\
\hline ESRP area & - & $188.5 \mathrm{ha}$ & - & $183 \mathrm{ha}$ & - & $168.7 \mathrm{ha}$ \\
\hline
\end{tabular}

species, El. cingulata and Eg. securigera, were only recorded in the last sampling and the considerable augment several times in abundance of both Eg . cordata and El . nigrita contributed to the higher species diversity observed in 2018/2019. Contrarily, in four samplings carried out during a 7-year span in a forest fragment within an urban area, Nemésio et al. (2015) recorded the same values of species richness in the first and last samplings, but the abundance decreased ca $36 \%$ from the first to the last sampling. Roubik and Ackerman (1987) stressed that the abundance tended to reduce for the first 2 years of sampling in two sites but after that period it increased and stabilised. In a protected moist forest in Panama, Roubik (2001) observed that the raw abundance of each orchid bee species varied from about 3- to 14-fold across 21 years of sampling. It is possible that discrepancies concerning abundance values might be due to biases from samplers since each sampling made in the ESRP was conducted by a different researcher. Allen et al. (2019) pointed out that these studies on surveys, especially those performed simultaneously in different areas, are subjected to biases arising from study design and the assistance of volunteers. In order to attenuate these problems, the authors randomised the location of the teams besides training and pairing experienced staff with inexperienced samplers.

Temperature was an important abiotic factor to explain variations in euglossine males' abundance in the ESRP since the monthly values were positively correlated with the number of bees sampled in two samplings. Cândido et al. (2018) also observed that temperature may have been one of the aspects that influenced bee abundance in the forest fragments studied in an urban zone. However, there was no correlation between monthly rainfall and orchid bee abundance over the sampling years in our study, what suggests that some other abiotic or biotic factors might be influencing the bee diversity in the area. Giangarelli et al. (2015a) studied euglossine communities in three different vegetal physiognomies of Atlantic forest and reported that both rainfall and temperature were important variables influencing males' abundance in a rainforest fragment but both factors were not sufficient to explain the similarity between the mixed and semideciduous forest fragments, which are situated under the same climate conditions.

Even though a negative value of SI was estimated for the community sampled in the ESRP, which indicates a stable community (Roubik and Ackerman 1987), the orchid bee community studied herein was characterised by lower stability (1.13) when compared with other euglossine bee communities with higher values of SI sampled in Brazil (-1.81) (Nemésio et al. 2015) and in Panama $(-1.34,-1.5$, and -1.71$)$ (Roubik and Ackerman 1987). Whilst some species were highly stable such as Eg . pleosticta (-2.98), others fluctuated widely, with either sharp increases ($0.25 ; E g$. cordata) or reduction $(-0.1 ; E g$. annectans $)$ across the years. Our data are similar 
Table III.. Percentage of 10 land cover units measured from satellite images of 5, 10, and 20-km radii from the sampling area (ESRP) in three different years: 1990, 1998, and 2018

\begin{tabular}{|c|c|c|c|c|c|c|}
\hline \multirow[t]{2}{*}{ Land cover units } & \multicolumn{2}{|c|}{1990} & \multicolumn{2}{|c|}{1998} & \multicolumn{2}{|c|}{2018} \\
\hline & $\%$ & Area (ha) & $\%$ & Area (ha) & $\%$ & Area (ha) \\
\hline \multicolumn{7}{|c|}{$5-\mathrm{km}$ radius } \\
\hline Natural vegetation area & 7.2 & 788.5 & 4.5 & 493.7 & 9.3 & 1017.1 \\
\hline Agricultural lands & 74.1 & 8070.8 & 73.1 & 7964.6 & 57.4 & 6256.7 \\
\hline Urban areas & 13.7 & 1497.2 & 18.7 & 2034.5 & 32.8 & 3574.4 \\
\hline Water & 0.1 & 14.2 & 0.1 & 12.4 & 0.1 & 15.4 \\
\hline Other cover types & 4.8 & 528 & 3.6 & 393.3 & 0.3 & 35 \\
\hline \multicolumn{7}{|c|}{$10-\mathrm{km}$ radius } \\
\hline Natural vegetation area & 6.3 & 2340.2 & 4.3 & 1602.1 & 6.9 & 2575.4 \\
\hline Agricultural lands & 75.9 & $28,309.4$ & 75.5 & $28,149.4$ & 64.6 & $24,077.8$ \\
\hline Urban areas & 14.2 & 5309 & 18 & 6725.6 & 28 & $10,448.4$ \\
\hline Water & 0.2 & 61.7 & 0.1 & 45.5 & 0.2 & 73.8 \\
\hline Other cover types & 3.4 & 1265.1 & 2 & 762 & 0.3 & 106.6 \\
\hline \multicolumn{7}{|c|}{ 20-km radius } \\
\hline Natural vegetation area & 7.7 & $10,565.6$ & 6.8 & 9321.4 & 8.7 & 11,886 \\
\hline Agricultural lands & 84.6 & $115,967.8$ & 84 & $115,241.1$ & 77.4 & 106,124 \\
\hline Urban areas & 5.7 & 7860.5 & 7.7 & $10,578.1$ & 13.2 & $18,063.2$ \\
\hline Water & 0.4 & 559.1 & 0.4 & 495.5 & 0.4 & 577.2 \\
\hline Other cover types & 1.6 & 2197.6 & 1.1 & 1512.8 & 0.4 & 498.2 \\
\hline
\end{tabular}

to what was documented by Wolda (1992), who observed that the abundance fluctuation patterns of different insect taxa were extremely variable despite the apparently preserved, undisturbed studied forest ecosystem monitored during 14 years. The author also concluded that changes in time are likely the rule rather than the exception, even in well-preserved habitats such as a tropical forest in Panama. Indeed, large variations in the stability of moth species' populations were observed by Wolda et al. (1992) in two discrepant ecosystems in Czechia, particularly at the very unstable agricultural setting when compared with the temporally constant wet alder forest.

Besides the lower stability, species turnover was observed herein with the increase in abundance of a plastic species until its high prevalence reached in the last sampling year. In contrast, the dominant species of both 1990/1991 and 1998/ 1999 samplings, Eg. pleosticta, was stable throughout the years and became the third most abundant orchid bee in the ESRP due to the high augment in abundance of Eg. cordata and El. nigrita. Thus, our second hypothesis on a higher number of species commonly found in urban and/ or altered areas was confirmed by the data presented herein. The increase in number of these two resilient species may be related to the augment of urban area percentage within Ribeirão Preto city across 28 years. Euglossa cordata is a widely distributed species in South America and occurs in several ecosystems ranging from pristine forests to open environments and disturbed areas (Raw 1989; Tonhasca et al. 2002; MiletPinheiro and Schlindwein 2005; Ramalho et al. 2009; Aguiar and Gaglianone 2012; Rocha-Filho and Garófalo 2013; Rosa et al. 2015; Carneiro et al. 2018). Moreover, this species is frequently recorded in cities (López-Uribe et al. 2008) and is highly generalist regarding floral resources collection (Ferreira-Caliman et al. 2018), what denotes its ecological plasticity and resilience. Likewise, El . nigrita can also be regarded as a highly resilient species since its occurrence has been largely 
documented in preserved ecosystems but also in human-altered areas and forest fragments immersed in urban and agricultural matrices (Tonhasca et al. 2002; Ramalho et al. 2009; Aguiar and Gaglianone 2012; Knoll and Penatti 2012; Storck-Tonon et al. 2013; Nemésio et al. 2015; Rosa et al. 2015; Cândido et al. 2018). Another species that reached high abundance in the present study was Eg. fimbriata, which was described as highly tolerant to open or altered areas (Nemésio et al. 2015).

On the other hand, the abundance of $E g$. annectans decreased throughout the different sampling years until zero in the fieldwork performed between 2018 and 2019. This species has been sampled mostly in large and preserved seasonal semideciduous forest or rainforest fragments (Aguiar and Gaglianone 2012; Knoll and Penatti 2012; Giangarelli et al. 2015a; Ferronato et al. 2018), especially at high altitudes, where it can reach increased dominance values (Pinto et al. 2019). Data from these studies seems to indicate Eg. annectans as a presumed bioindicator of environmental quality. Indeed, the analyses of diploid males of six orchid bee species sampled in different forest fragments revealed the highest frequencies in $E g$. annectans, especially in disturbed habitats when compared to preserved areas, which led Giangarelli et al. (2015b) to regard this species as potentially sensitive to altered habitats. Likewise, Ferronato et al. (2018) also suggested this species as a putative indicator of good habitat quality based on samplings of males that occurred exclusively in the most preserved reforested area compared with other three remnants surveyed. Nonetheless, in spite of the apparent strong association between $E g$. annectans and preserved forested areas, some literature data also shows that this species might not be susceptible to altered/fragmented habitats. For instance, Nemésio et al. (2015) calculated high stability for this species (cited as $E g$. stellfeldi Moure) in a 90-ha urban forest remnant where it was one of the most sampled orchid bee species. Besides, Grassi-Sella et al. (2018) concluded that forest fragmentation may not represent a constraint for $\mathrm{Eg}$. annectans males since no population structure was detected among samples analysed from six forest fragments distant from each other up to $342 \mathrm{~km}$. As Eg. annectans is highly abundant in large, preserved semideciduous forest fragments (Knoll and Penatti 2012; Ferronato et al. 2018), the decline in males' abundance of this species recorded in the present study might indicate a species susceptibility to habitat fragmentation, mainly when it is considered the reduction in size of the forest fragments located in the region of the ESRP. Notwithstanding, the suggestion of orchid bee species as bioindicators of disturbed areas should be made with caution, mainly when only data on alpha diversity are available, as in the present study, since this parameter was revealed to be a weak metric to disturbance (Allen et al. 2019).

Our findings demonstrate that even a small forest fragment within an urbanised landscape and subjected to different levels of anthropogenic impacts over the years (Leonel et al. 2010; Turioni 2014) harbours a diverse euglossine fauna. In contrast, long-term studies on bee assemblage conducted in Curitiba, Brazil, revealed dramatic decreases in both species richness and abundance possibly related to the increase in paved areas, land occupation, and urban population (Martins et al. 2013; Cardoso and Gonçalves 2018). Nevertheless, it is important to emphasise that the great bee abundance recorded in the present study belonged to two resilient species, Eg . cordata and $E l$. nigrita, and one likely susceptible species to disturbance, Eg. annectans, was absent in the recent sampling. Despite the increase of the natural vegetated area from 1998 to 2018 within up to $20-\mathrm{km}$ radius, the reduction in size of the small forest fragments imbedded in the ESRP buffer zone throughout the years is worrisome since these remnants might act as biological corridors to orchid bee species in a fragmented landscape (Rosa et al. 2015). Varanda et al. (2015) highlighted that measures of forest restoration within the ESRP buffer zone should be focused on forest corridors and enrichment of the fragments, especially the riparian forests; these practices would allow then the structural connectivity between green areas nearby streams and minimise the impact of edge effect. Therefore, not only preserving and maintaining forest fragments in urban areas but also restoring them after environmental impacts would be relevant procedures to support a 
species-rich, native flora, and fauna. Moreover, reforested habitats adjacent to forest remnants may play an important role to reinstate orchid bee communities, what should be considered by authorities in future actions of reforestation of disturbed areas (Ferronato et al. 2018).

\section{ACKNOWLEDGEMENTS}

The authors are grateful to the ESRP staff for assistance and allowing the fieldwork in the area, to José Carlos Serrano (FFCLRP) for field assistance and technical support, to Gabriel Blain (IAC) for providing the climate data from 1990, and to 'Coordenação de Aperfeiçoamento de Pessoal de Nível Superior (CAPES)' for granting a PNPD scholarship to the first author.

Contributions LCRF conceived this research and wrote the manuscript; PCM and DB conducted the landscape analysis; PCM, DB and CAG participated in the revision. All authors read and approved the final manuscript.

Turnover d'espèces et faible stabilité dans une communauté d'abeilles euglossine (Hymenoptera : Apidae) échantillonnée dans un fragment de forêt urbaine, pendant 28 ans.

Euglossa cordata / Eulaema nigrita / abeille à orchidées / espèce résiliente.

Artenwechsel und geringe Stabilität in einer Gemeinschaft von Euglossinen (Hymenoptera: Apidae), die über einen Zeitraum von 28 Jahren in einem urbanen Waldfragment gesammelt wurden.

Euglossa cordata / Eulaema nigrita / Prachtbienen/ resiliente Arten.

\section{REFERENCES}

Aguiar, W.M., Gaglianone, M.C. (2012) Euglossine bee communities in small forest fragments of the Atlantic Forest, Rio de Janeiro state, southeastern Brazil (Hymenoptera, Apidae). Rev. Bras. Entomol. 56 (2), 210 219 . https://doi.org/10.1590/S008556262012005000018

Allen, L., Reeve, R., Nousek-McGregor, A., Villacampa, J., MacLeod, R. (2019) Are orchid bees useful indicators of the impacts of human disturbance? Ecol. Indic. 103, 745-755. https://doi.org/10.1016/j. ecolind.2019.02.046

Ascher, J.S., Pickering, J. (2020) Discover Life bee species guide and world checklist (Hymenoptera: Apoidea: Anthophila). Available at https://www.discoverlife. $\mathrm{org} / \mathrm{mp} / 20 \mathrm{q}$ ?\%20guide=Apoidea_species.htm. Accessed Feb/28/2020

Banaszak-Cibicka, W., Żmihorski, M. (2012) Wild bees along an urban gradient: winners and losers. J. Insect Conserv. 16 (3), 331-343. https://doi.org/10.1007 /s10841-011-9419-2

Botsch, J.C., Scott, T.W., Jordan, K., González, N., Dobbs, E.K., Brosi, B.J. (2017) Impacts of forest fragmentation on orchid bee (Hymenoptera: Apidae: Euglossini) communities in the Chocó biodiversity hotspot of northwest Ecuador. J. Insect Conserv. 21 (4), 633643. https://doi.org/10.1007/s10841-017-0006-Z

Brosi, B.J. (2009) The effects of forest fragmentation on euglossine bee communities (Hymenoptera: Apidae: Euglossini). Biol. Conserv. 142 (2), 414-423. https://doi.org/10.1016/j.biocon.2008.11.003

Butchart, S.H.M., Walpole, M., Collen, B., van Strien, A., Scharlemann, J.P.W., et al. (2010) Global Biodiversity: Indicators of Recent Declines. Science 328 (5982), 1164-1168. https://doi.org/10.1126/science.1187512

Cândido, M.E.M.B., Morato, E.F., Storck-Tonon, D., Miranda, P.N., Vieira, L.J.S. (2018) Effects of fragments and landscape characteristics on the orchid bee richness (Apidae: Euglossini) in an urban matrix, southwestern Amazonia. J. Insect Conserv. 22 (3-4), 475486. https://doi.org/10.1007/s10841-018-0075-7

Cardoso, M.C., Gonçalves, R.B. (2018) Reduction by half: the impact on bees of 34 years of urbanization. Urban. Ecosyst. 21 (5), 943-949. https://doi.org/10.1007 /s11252-018-0773-7

Carneiro, L.S., Aguiar, W.M., Aguiar, C.M.L., Santos, G.M.M. (2018) Orchid bees (Hymenoptera: Apidae: Euglossini) in seasonally dry tropical forest (Caatinga) in Brazil. Sociobiology 65 (2), 253-258. https://doi. org/10.13102/sociobiology.v65i2.2077

CIIAGRO (2019) Resenha Agrometeorológica. Available at http://www.ciiagro.sp.gov/. Accessed Jun/02/2019

Cordeiro, M., Garraffoni, A.R.S., Lourenço, A.P. (2019) Rapid assessment of the orchid bee fauna (Hymenoptera: Apidae: Euglossini) in the vicinity of an urban Atlantic Forest remnant in São Paulo, Brazil. Braz. J. Biol. 79 (1), 149-151. https://doi.org/10.1590/15196984.171286

Cortopassi-Laurino, M., Zillikens, A., Steiner, J. (2009) Pollen sources of the orchid bee Euglossa annectans Dressler 1982 (Hymenoptera: Apidae, Euglossini) analyzed from larval provisions. Genet. Mol. Res. 8 (2), 546-556. https://doi.org/10.4238/vol8-2kerr013

Dodson, C.H. (1966) Ethology of some bees of the tribe Euglossini (Hymenoptera: Apidae). J Kansas Entomol. Soc. 39 (4), 607-629

Dressler, R.L. (1982) Biology of the orchid bees (Euglossini). Annu. Rev. Ecol. Syst. 13 (1), 373- 
394. https://doi.org/10.1146/annurev. es.13.110182.002105

Elias, D. (2003) Globalização e agricultura: A região de Ribeirão Preto-SP. Edusp, São Paulo

Ferreira-Caliman, M.J., Rocha-Filho, L.C., Freiria, G.A., Garófalo, C.A. (2018) Floral sources used by the orchid bee Euglossa cordata (Linnaeus, 1758) (Apidae: Euglossini) in an urban area of south-eastern Brazil. Grana 57 (6), 471-480. https://doi.org/10.1080 /00173134.2018.1479445

Ferronato, M.C.F., Giangarelli, D.C., Mazzaro, D., Uemura, N., Sofia, S.H. (2018) Orchid Bee (Apidae: Euglossini) communities in Atlantic Forest remnants and restored areas in Paraná State, Brazil. Neotrop. Entomol. 47 (3), 352-361. https://doi.org/10.1007 /s13744-017-0530-2

Garófalo, C.A., Rozen, J.G. (2001) Parasitic behavior of Exaerete smaragdina with descriptions of its mature oocyte and larval instars (Hymenoptera: Apidae: Euglossini). Am. Mus. Novit. 3349, 1-26.

Giangarelli, D.C., Freiria, G.A., Colatreli, O.P., Suzuki, K.M., Sofia, S.H. (2009) Eufriesea violacea (Blanchard): a euglossine species potentially sensitive to forest patch deterioration in Brazil. Neotrop. Entomol. 38 (5), 610-615. https://doi.org/10.1590 /S1519-566X2009000500008

Giangarelli, D.C., Aguiar, W.M., Sofia, S.H. (2015a) Orchid bee (Hymenoptera: Apidae: Euglossini) assemblages from three different threatened phytophysiognomies of the subtropical Brazilian Atlantic Forest. Apidologie 46 (1), 71-83. https://doi. org/10.1007/s13592-014-0303-4

Giangarelli, D.C., Freiria, G.A., Ferreira, D.G., Aguiar, W.M., Penha, R.E.S., Alves, A.N., Gaglianone, M.C., Sofia, S.H. (2015b) Orchid bees: a new assessment on the rarity of diploid males in populations of this group of Neotropical pollinators. Apidologie 46 (5), 606-617. https://doi.org/10.1007/s13592-015$0350-5$

Gibson, L., Lee, T.M., Koh, L.P., Brook, B.W., Gardner, T.A., Barlow, J., Peres, C.A., Bradshaw, C.J.A., Laurance, W.F., Lovejoy, T.E., Sodhi, N.S. (2011) Primary forests are irreplaceable for sustaining tropical biodiversity. Nature 478 (7369), 378-381. https://doi. org/10.1038/nature10425

Grassi-Sella, M.L., Garófalo, C.A., Francoy, T.M. (2018) Morphological similarity of widely separated populations of two Euglossini (Hymenoptera; Apidae) species based on geometric morphometrics of wings. Apidologie 49 (2), 151-161. https://doi.org/10.1007 /s13592-017-0536-0

Hammer, Ø., Harper, D.A.T., Ryan, P.D. (2001) PAST: Paleontological statistics software package for education and data analysis. Palaeontol. Electron. 4 (1), 1-9

Harrison, T., Gibbs, J., Winfree, R. (2017) Forest bees are replaced in agricultural and urban landscapes by native species with different phenologies and life-history traits. Global Change Biol. 24 (1), 287-296. https://doi.org/10.1111/gcb.13921
IBGE (2020) Cidades, IBGE, Rio de Janeiro. Available at https://cidades.ibge.gov.br/brasil/sp/ribeiraopreto/panorama. Accessed Feb/28/2020

Janzen, D.H. (1971) Euglossine bees as long distance pollinators of tropical plants. Science 171 (3967), 203205. https://doi.org/10.1126/science.171.3967.203

Jesus, B.M.V. (2000) Riqueza e abundância sazonal de Euglossini (Hymenoptera, Apidae) em fragmentos de matas do Estado de São Paulo. PhD Thesis. University of São Paulo, Ribeirão Preto, SP, Brazil

Knoll, F.R.N., Penatti, N.C. (2012) Habitat fragmentation effects on the orchid bee communities in remnant forests of southeastern Brazil. Neotrop. Entomol. 41 (5), 355-365. https://doi.org/10.1007/s13744-012$0057-5$

Kotchetkoff-Henriques, O., Joly, C.A., Bernacci, L.C. (2005) Soil and floristic composition of native vegetation remnants relationship in the municipality of Ribeirão Preto, SP. Rev. Bras. Bot. 28 (3), 541-562. https://doi.org/10.1590/S0100-84042005000300011

Leonel, C., Nalon, M.A., Thomaziello, S., Oliveira, C., Zancheta, D., Kotchetkoff-Henriques, O., Bosco, J. (2010) Plano de Manejo da Estação Ecológica de Ribeirão Preto, Mata de Santa Tereza: volume principal e anexos. Secretaria do Meio Ambiente, Ribeirão Preto, Brazil. Available at http://arquivos.ambiente.sp. gov.br/fundacaoflorestal/2012/01/EERP-Vol-principal.pdf. Accessed Jun/02/2019

López-Uribe, M.M., Oi, C.A., Del Lama, M.A. (2008) Nectar-foraging behavior of Euglossine bees (Hymenoptera: Apidae) in urban areas. Apidologie 39 (4), 410-418. https://doi.org/10.1051/apido:2008023

MapBiomas (2019) Coleção v.3.1 da Série Anual de Mapas de Cobertura e Uso de Solo do Brasil. Available at http://mapbiomas.org. Accessed Aug/21/2019

Martins, A.C., Gonçalves, R.B., Melo, G.A.R. (2013) Changes in wild bee fauna of a grassland in Brazil reveal negative effects associated with growing urbanization during the last 40 years. Zoologia 30 (2), 157176. https://doi.org/10.1590/S198446702013000200006

Mateus, S., Andrade-Silva, A.C.R., Garófalo, C.A. (2015) Diversity and temporal variation in the orchid bee community (Hymenoptera: Apidae) of a remnant of a Neotropical seasonal semi-deciduous forest. Sociobiology 62 (4), 571-577. https://doi.org/10.13102/sociobiology.v62i4.391

McGarigal, K., Cushman, S.A., Ene, E. (2012) FRAGSTATS v4: Spatial pattern analysis program for categorical and continuous maps. Computer software program produced by the authors at the University of Massachusetts, Amherst. Available at: h t t p : / / w w w. u m a s s . edu/landeco/research/fragstats/fragstats.html. Accessed Nov/18/2019

Michener, C.D. (2007) The Bees of the World. 2nd. The John Hopkins University Press, Baltimore

Milet-Pinheiro, P., Schlindwein, C. (2005) Do Euglossine males (Apidae, Euglossini) leave tropical rain forest to collect fragrances in sugar cane monocultures? Rev. 
Bras. Zool. 22 (4), 853-858. https://doi.org/10.1590 /S0101-81752005000400008

Nemésio, A., Santos, L.M., Vasconcelos, H.L. (2015) Long-term ecology of orchid bees in an urban forest remnant. Apidologie 46 (3), 359-368. https://doi. org/10.1007/s13592-014-0328-8

Ospina-Torres, R., Montoya-Pfeiffer, P.M., Parra-H, A., Solarte, V., Otero, J.T. (2015) Interaction networks and the use of floral resources by male orchid bees (Hymenoptera: Apidae: Euglossini) in a primary rain forests of the Chocó Region (Colombia). Rev. Biol. Trop. 63 (3), 647-658

Pinto, A.R., Silveira, G.C., Gaglianone, M.C., Freitas, L. (2019) Abrupt decrease in the diversity of Euglossini bees (Hymenoptera: Apidae) in a montane rainforest. J. Apicult. Res. 58 (5), 682-693. https://doi.org/10.1080 /00218839.2019.1637223

Pokorny, T., Loose, D., Dyker, G., Quezada-Euán, J.J.G., Eltz, T. (2015) Dispersal ability of male orchid bees and direct evidence for long-range flights. Apidologie 46 (2), 224-237. https://doi.org/10.1007/s13592-014$0317-\mathrm{y}$

Powell, A.H., Powell, V.N. (1987) Population dynamics of male euglossine bees in Amazonian forest fragments. Biotropica 19 (2), 176-179. https://doi.org/10.2307 $/ 2388742$

Ramalho, A.V., Gaglianone, M.C., Oliveira, M.L. (2009) Comunidades de abelhas Euglossina (Hymenoptera: Apidae) em fragmentos de Mata Atlântica no Sudeste do Brasil. Rev. Bras. Entomol. 53 (1), 95-101. https://doi.org/10.1590/S0085-56262009000100022

Ramírez-Arriaga, E., Hernández, E.M. (1998) Resources foraged by Euglossa atroveneta (Apidae: Euglossinae) at Union Juárez, Chiapas, Mexico. A palynological study of larval feeding. Apidologie 29 (4), 347-359. https://doi.org/10.1051/apido:19980405

Rathcke, B.J., Jules, E.S. (1993) Habitat fragmentation and plant-pollinator interactions. Curr. Sci. 65 (3), 273277.

Raw, A. (1989) The dispersal of Euglossine bees between isolated patches of eastern Brazilian wet forest (Hymenoptera, Apidae). Rev. Bras. Entomol. 33 (1), 103107.

Rebêlo, J.M.M., Garófalo, C.A. (1991) Diversidade e sazonalidade dos machos de Euglossini (Hymenoptera: Apidae) e preferências por iscas-odores em um fragmento de floresta no sudeste do Brasil. Rev. Bras. Biol. 51 (4), 787-799

Rebêlo, J.M.M., Garófalo, C.A. (1997) Comunidades de machos de Euglossini (Hymenoptera: Apidae) em matas semidecíduas do nordeste do Estado de São Paulo. An. Soc. Entomol. Bras. 26 (2), 243-255. https://doi.org/10.1590/S0301-80591997000200005

Rebêlo, J.M.M., Moure, J.S. (1995) As espécies de Euglossa Latreille do Nordeste de São Paulo (Apidae, Euglossinae). Rev. Bras. Zool. 12 (3), 445-466. https://doi.org/10.1590/S0101-81751995000300001

Rocha-Filho, L.C., Garófalo, C.A. (2013) Community ecology of euglossine bees in the coastal Atlantic
Forest of São Paulo State, Brazil. J. Insect Sci. 13 (1), article 23. https://doi.org/10.1673/031.013.2301

Rocha-Filho, L.C., Krug, C., Silva, C.I., Garófalo, C.A. (2012) Floral resources used by Euglossini bees (Hymenoptera: Apidae) in coastal ecosystems of the Atlantic forest. Psyche 2012, 1-13. https://doi. org/10.1155/2012/934951

Rosa, J.F., Ramalho, M., Monteiro, D., Silva, M.D. (2015) Permeability of matrices of agricultural crops to Euglossina bees (Hymenoptera, Apidae) in the Atlantic Rain Forest. Apidologie 46 (6), 691-702. https://doi. org/10.1007/s13592-015-0359-9

Roubik, D.W. (2001) Ups and downs in pollinator populations: When is there a decline? Conserv. Ecol. 5 (1), 2. Available at http://www.consecol.org/vol5/iss1/art2/. Accessed Feb/28/2020. https://doi.org/10.5751/ES00255-050102

Roubik, D.W., Ackerman, J.D. (1987) Long-term ecology of euglossine orchid-bees (Apidae, Euglossini) in Panama. Oecologia 73 (3), 321-333. https://doi. org/10.1007/BF00385247

Roubik, D.W., Hanson, P.E. (2004) Orchid bees of tropical America: Biology and field guide. Instituto Nacional de Biodiversidad (INBio), Heredia, Costa Rica

Sánchez-Bayo, F., Wyckhuys, K.A.G. (2019) Worldwide decline of the entomofauna: A review of its drivers. Biol. Conserv. 232, 8-27. https://doi.org/10.1016/j. biocon.2019.01.020

Santos, A.M., Sofia, S.H. (2002) Horário de atividade de machos de Euglossinae (Hymenoptera, Apidae) em um fragmento de floresta semidecídua no Norte do Estado do Paraná. Acta Sci. 24 (2), 375-381

Sofia, S.H., Santos, A.M., Silva, C.R.M. (2004) Euglossine bees (Hymenoptera, Apidae) in a remnant of Atlantic Forest in Paraná State, Brazil. Iheringia, Sér. Zool. 94 (2), 217-222. https://doi.org/10.1590/S007347212004000200015

Storck-Tonon, D., Morato, E.F., Melo, A.W.F., Oliveira, M.L. (2013) Orchid Bees of forest fragments in Southwestern Amazonia. Biota Neotrop. 13 (1), 133-141. https://doi.org/10.1590/S1676-06032013000100015

Tonhasca, A., Blackmer, J.L., Albuquerque, G.S. (2002) Abundance and diversity of euglossine bees in the fragmented landscape of the Brazilian Atlantic forest. Biotropica 34 (3), 416-422. https://doi.org/10.1111 /j.1744-7429.2002.tb00555.x

Turioni, F. (2014) Fogo destruiu 72 hectares de reserva e recuperação pode custar $\mathrm{R} \$ 400$ mil. Available at http://g1.globo.com/s p/ribeirao-pretofranca/noticia/2014/09/fogo-destruiu-72-hectares-dereserva-e-recuperacao-pode-custar-r-400-mil.html. Accessed June 02/2019

Varanda, E.M., Lapenta, M.J., Gimenez, V.M.M., Vasters, M.P., Santos, H.F., Barosela, J.R., Donadio, N.M.M., Gaioso-Rafael, L.F., Oliveira, C. (2015) Áreas prioritárias ao restabelecimento da conectividade estrutural entre fragmentos florestais da zona de amortecimento da Estação Ecológica de Ribeirão Preto. Rev. Inst. Flor. 27 (1), 49-71. https://doi. org/10.4322/rif.2015.005 
Wolda, H. (1983) Long-term stability of tropical insect populations. Res. Popul. Ecol. Suppl. 3, 112-126. https://doi.org/10.1007/BF02539633

Wolda, H. (1992) Trends in abundance of tropical forest insects. Oecologia 89 (1), 47-52. https://doi. org/10.1007/BF00319014

Wolda, H., Spitzer, K., Lepš, J. (1992) Stability of environment and of insect populations. Res. Popul. Ecol. 34 (2), 213-225. https://doi.org/10.1007/BF02514794
Zar, J.H. (1996) Biostatistical analysis. Prentice-Hall, Upper Saddle River

Publisher's note Springer Nature remains neutral with regard to jurisdictional claims in published maps and institutional affiliations. 